\title{
Constraints and Suggestion in Marketing of Cattle in Beed District of Maharashtra, India
}

\author{
V.S. Thombre ${ }^{1}$, R.D. Shelke ${ }^{1 *}$ and A.B. Ingle ${ }^{2}$ \\ ${ }^{1}$ Department of Agricultural Economics, College of Agriculture, Latur, India \\ ${ }^{2}$ College of Agriculture, Umarkhed, India \\ *Corresponding author
}

\section{A B S T R A C T}

\section{Keywords}

Constraints, Suggestion, Cattle, Market and Beed

Article Info

Accepted:

20 October 2020

Available Online:

10 November 2020
Multistage sampling design was adopted to study the constraints in marketing of cattle in Beed district of Maharashtra. The study sample comprised of two cattle market 15 sellers, 15 buyers and 15 middlemen from each market were selected randomly. The study revealed that Hatta method of sale and inadequate market facility were the top two constraints ranked by seller and buyers in in cattle market

\section{Introduction}

Livestock sector includes animal husbandry, dairy and fisheries sector are considerable major sector. It plays an important role in National economy and social economic development of the country. It also plays important role in the rural economy as supplementing family incomes and generating gainful employment in the rural sector. Indian livestock industry makes up for a significant amount of world's livestock resources.

India rank first in total milk production. In the year 2018-19 total production of milk in India is 187.7 million tonnes, which was 22 per cent of that year's global total milk production of 843 million tonnes. Due to their high production per capita availability of milk in India is 394 (gms/ day). India's biggest milk producing states are Uttar Pradesh then Rajasthan, Andhra Pradesh and Gujarat state respectively. Maharashtra state ranks $7^{\text {th }}$ in total production of India. Total production of milk in Maharashtra state is 11.10 MT. Source: (Basic Animal Husbandry Statistics, DAHD \& F, GoI).

The main objectives include to Study the Constraints and Suggesting in Marketing of Cattle. 


\section{Materials and Methods}

\section{Selection of market}

Beed district was selected purposively, because maximum animals of livestocks in Beed district market as compared to other district market. Beed district cattle market is the gateway to the Marathwada, where marketing of various types of animals take place.

\section{Selection of cattle market}

Ambajogai cattle market and salegaon cattle market was selected

\section{Sampling design}

Multistage sampling design was adopted in selection of district, taluka and villages on the basis of highest cattle population.

\section{Selection of district}

At first stage, the Beed district was purposively selected.

\section{Selection of talukas}

Two talukas viz. Ambajogai and Kaij (Salegaon) was selected on the basis of highest cattle population.

\section{Selection of villages}

From each taluka three villages viz. Undri, Esthal, Bansarola, Mudegaon, Dethna and Nandgaon was selected randomly. Thus, in all 6 villages from the two talukas will be selected.

\section{Selection of buyer, seller and middleman}

5 buyer, 5 seller, 5 middlemen will be selected from each village.

\section{Results and Discussion}

\section{Constraints in marketing of different kinds} of animal

In Beed district cattle market and process of sale and purchase of the animals depends upon the type of market in Beed District cattle market seller, buyer and broker play important role in marketing of cattle. Constraints faced by these categories ware of deferent nature. Due to the regulated market several problems are faced by the above said categories (Table 1). It is important to know the contract so as suggest the suitable remedies and imprudent to overcome the constraints. The details regarding constraints in encountered in marketing of cattle and different level are as follows.

\section{Farmers / cultivators / sellers}

Constraints expressed while marketing of the animals by the farmer are presented.

In all of 60 farmers i.e. 30 seller and 30 buyer more constraints are faced while at the time selling and purchasing of animal. Major constraints faced by seller and buyer are method of sell which is commonly known as Hatta or under cover method. In that method both buyer and seller are completely ignorant and both are not benefited they may be cheated by broker in fixing final price by negotiation. Other constrains faced by seller are inadequate market facility no guarantee of performance of animal, market fees are not well defined, no credit facility, brokerage charge are not fixed these are some constraint faced by farmer/ cultivators/ seller.

Absence of inadequate market facilities included space for examining the animals, water supply, sheds and lodging facility to the buyer seller in the market. 
Table.1 Constraints of farmers in marketing of animal (seller and buyer)

\begin{tabular}{|l|l|c|c|}
\hline Sr.No. & Particulars & No. of Farmer & Percentage (\%) \\
\hline $\mathbf{1}$ & Hatta Method of sale & 55 & 91.66 \\
\hline $\mathbf{2}$ & Inadequate market facility & 25 & 41.66 \\
\hline $\mathbf{3}$ & Brokerage charge are not fixed & 15 & 25 \\
\hline $\mathbf{4}$ & Market fees not well defined & 18 & 30 \\
\hline $\mathbf{5}$ & Insufficient time for transaction & 12 & 20 \\
\hline
\end{tabular}

\section{Brokers}

As like the seller and buyer in the market, broker has faced some problem in cattle market. As like procedure is clumsy for getting a permission to become a authorized broker. They have to pass through long channel for getting the authorization also they have faced many problems at time of market. These are undefined sale process, customer experience, lead generation, work-flow efficiency, uncertainty in the market, new and emerging risk and cheating through seller and buyer.

\section{Suggestion in marketing of cattle}

\section{Seller suggestion}

It is important to know the contract so as suggest the suitable remedies and imprudent to overcome the constraints. Seller gives suggestion for better marketing of cattle. These suggestions are Increase the no. of buyer in the market due to this there will be great demand for cattle price. Then provides animal shed this suggestion is useful for seller for protecting the animal from sunlight. Then Reduce cheating through broker, some restriction on broker is needed. And lastly providing facility like road, water etc. These are some suggestion given through seller.

\section{Buyer suggestion}

It is important to know the contract so as suggest the suitable remedies and imprudent to overcome the constraints. Buyer gives suggestion for better marketing of cattle. These suggestions are Increased size of the market this will be useful for select the good cattle in the market. Then provide the parking space near the cattle market, Increase the no. of seller in the market this will be helpful for selecting the animal in the market and provide banking facility near the market these are the suggestion given from the buyer.

\section{Broker/ Middleman suggestion}

It is important to know the contract so as suggest the suitable remedies and imprudent to overcome the constraints. Broker gives suggestion for better marketing of cattle. These are Increase the no. of Buyer and seller in the market, providing the banking facility near the market, Develop the internal road in the market and providing parking space near the market.

\section{References}

Beohar B. B., Mishra P.K. and Nahatkar (2007) Livestock marketing problem in Madhya Pradesh. Ind .Jn. of Agri. Econ. 62(3): 471-472.

Choudhary, V.K. (2007) Economics of production, marketing and constraints of buffalo milk Indore district of Madhya Pradesh. Ind. Jn. of Agri. Econ. 62 (3): 482-483.

Kathirav. and Selvam, S. (2011) Analysis of 
constraints to livestock production in Tamil Nadu. Agricultural research communication. 45(1):57-59.

Kgosikoma K. and Malope P. (2016) Determinants of market participations and the institutional constraints. Journal of agricultural extension and rural development. 8 (9) 178-186.

\section{How to cite this article:}

Thombre, V.S., R.D. Shelke and Ingle, A.B. 2020. Constraints and Suggestion in Marketing of Cattle in Beed District of Maharashtra. Int.J.Curr.Microbiol.App.Sci. 9(11): 2912-2915. doi: https://doi.org/10.20546/ijcmas.2020.911.353 